\title{
Legal studies on the halal product certification institution in Indonesia after the enactment of the law on the halal product guarantee
}

\author{
M. Sakti*, Pujiyono \& M.N. Imanullah \\ Universitas Sebelas Maret, Surakarta, Indonesia
}

\begin{abstract}
The implementation of the halal product certification in Indonesia is closely related to efforts to fulfill consumer rights, especially Muslim consumers. It is not only limited to consumer goods but also used goods such as clothing and services of tourism and hotels, which many people expect to be halal-guaranteed. Halal is also related to religious rules, but many people already understand that halal products are healthy and clean. In addition to protecting consumers, it can also increase the economic income of business actors. The halal certification process in Indonesia, which was initially under the authority of the Indonesian Ulema Council, has now shifted its authority after the enactment of the Halal Product Guarantee Law. The Indonesian Ulama Council is no longer the only institution authorized to certify halal products. However, there is a new institution under the Ministry of Religion, namely the Halal Product Guarantee Agency. In 2019, the scope of the Halal Product Guarantee Law should be adequate. Nevertheless, the news institution that organizes halal product certification is experiencing several obstacles, which then creates an impression in the community that the institution is not ready for and is ineffective in carrying out its role in implementing halal food certification in Indonesia.
\end{abstract}

Keywords: certification, institution, halal, product, guarantee

\section{INTRODUCTION}

Indonesia is a country with the largest Muslim population globally, with more than two hundred and seven million people or around $87 \%$ of the total Indonesian population. Despite being a predominantly Muslim country, Pancasila remains the Indonesian nation's ideology without reducing Islamic law values. In the 1945 Constitution Article 28E paragraph (1), it is stated that everyone is free to embrace a religion and worship according to their religion. This is the basis that the state must protect and guarantee to its citizens right to worship and ability to carry out the beliefs taught in their religion.

Islam is one of the religions recognized in Indonesia. Therefore, the state must protect and guarantee the Islamic religion's adherents to carry out worship by the Sharia taught by their religion. One thing that is taught is that Muslims are obliged to consume halal products by Islamic law. The word halal comes from Arabic, which means to let go and not to be bound. Etymologically, halal means things that can be done because they are free or not bound by the provisions that prohibit them or can mean anything free from harm (Putra 2017). Halal Products are also products that have been declared halal according to Islamic law.

The halal industry has experienced rapid development in recent years. The halal lifestyle that is synonymous with Muslims has spread to various countries, even to countries with minority Muslim populations. Halal is a universal indicator of product quality assurance and living standards (Gillani et al. 2016). However, the development of food technology has been so rapid that the use of ingredients in food processing has varied considerably - the development of the use of ingredients

\footnotetext{
${ }^{*}$ Corresponding author
} 
with specific desirable properties at low prices has become common. The problem is the number of food ingredients, both the primary raw materials and the addictive ingredients, which make it difficult to determine the ingredients' halal origin. The clarity of information on a product consumed is a halal product, or the legal provisions are not clear. Therefore, the existence of a halal label is an important thing to include in every food product. A halal label will make it easier for consumers to identify food products so that even without in-depth knowledge of food additives that allow using haram ingredients, consumers will feel safe when consuming food that is labeled halal. Even so, there are still Muslim consumers who ignore the halal label. Therefore, consumers' perceptions about the importance of information on a product's halal-ness need to be known so that the products released by the food industry are safe products for consumption both in terms of nutritional value and halal-ness.

Along with the law changes that regulate the guarantee of halal products in Indonesia, this cannot be separated from the lack of legal certainty regarding the guarantee of halal products in Indonesia. A few cases have happened to consumers in Indonesia, especially Muslim consumers, who feel disadvantaged because they have to consume foods that are not halal. It can be said that there is no halal label on the products they consume. For example, take meatballs containing pork in several parts of Indonesia and meningitis vaccine cases for pilgrims containing pork enzymes. If we look at this case, it can be said that one of the factors is an inconsistent, overlapping, and non-systemic regulatory system. To provide protection for consumers, the most fundamental thing is that the process of should be an mandatory for every business actor, but the regulations that apply at that time are still voluntary (Hasan 2014).

Of the various regulations that pertain to the guarantee of halal products at that time, it turned out that they still did not fully provide legal certainty to consumers, especially the Muslim community, regarding these regulations. Then in 2006, the People's Representative Council of the Republic of Indonesia (DPR RI), through a proposed initiative, proposed a Bill (RUU) on the Halal Product Guarantee, which was under discussion for eight years. In the end, the bill was passed by the President of the Republic of Indonesia to become law number 33 of 2014 on Halal Products Guarantee, on October 17, 2014. After being ratified and promulgated by law number 33 of 2014, Article 67 paragraph (1) of ingredients,' the law states for products circulating and traded in Indonesia's territory takes effect five years from the enactment of the law. It means that on October 17,2019 , the law came into effect. This confirms that every product that enters circulates and is traded in Indonesia's territory is required to be certified halal. In this case, through the Ministry of Religion of the Republic of Indonesia, the Government is responsible for organizing the Halal Product Guarantee (JPH). Thus, a Halal Product Guarantee Body was formed, which is domiciled under and responsible to the Minister of Religion of the Republic of Indonesia as the organizing Institution for guaranteeing halal products.

A legal concept that contains values, principles, concepts, and basic principles for the formation of the legal substance content of halal products is based on the real needs of the Indonesian people to improve the standard of living, economy, and freedom of practice of religious values and not solely based on business needs. Especially at the expense of the interests of the consumer community. Halal certification in Indonesia's National legal system has a central position because halal certification is contained in law number 33 of 2014, as part of the legal system, namely a legal substance with legal force and legal certainty. That is imperative. Moreover, this is an effort to protect consumers in Islamic Law (Putra 2017).

In connection with the enactment of law number 33 of 2014 on Halal Product Guarantee, this implies a change in the procedure and registration system for halal certification from voluntary to mandatory, which creates a new Institution called the Halal Product Guarantee Body. Thus, there was a shift in the authority for halal certification, which initially belonged to the Indonesian Ulema Council for Food, Drug and Cosmetics Assessment Institute (LPPOM MUI), recently shifted to the Halal Product Guarantee Body, and also affects the process of implementing halal product certification in Indonesia. Based on this background, the writer sees a problem. Namely, are the regulations on the Halal Product Guarantee Law's implementing bodies for halal product certification useful in implementing the halal certification procedure? 


\section{CERTIFICATION OF HALAL PRODUCTS AS CONSUMER PROTECTION}

When a country enters the stage of a welfare state, demands for government intervention through the formation of laws that protect the weak are extreme (Fishmen 1986). All halal products must follow Sharia law, including the logistical process. Logistics service providers play an essential role in ensuring that raw materials, raw materials, packaging, storage, and transportation of halal products are carried out properly to not be contaminated with non-halal products (Soon et al. 2017).

Talking about halal product certification, of course, is closely related to consumer protection. As consumers, the Indonesian people need certainty regarding the product's halal-ness, especially food. Consumers have a greater risk than business actors. In other words, consumer rights are very vulnerable. This is due to consumers' weak bargaining position, so that consumer rights are very vulnerable to being violated (Makarim 2003). Oughton and Lowry (1997) view consumer protection law as a modern phenomenon typical of the 20th century, but as confirmed in legislation, legal protection for consumers began a century earlier. The theory of legal protection is a theory related to providing services to the community.

Awareness in registering for halal product certification has not been a major priority for business actors in Indonesia. Compared to other countries, especially countries with most non-Muslim people, many have started to pay attention to and seek their products' halal label. This is not only to fulfill the rights of Muslim consumers, but these business actors also have the view to have more value in trade competition in the Muslim market. When the Muslim community sees that its products are halal certified, they will believe that already halal products are more controlled for quality. They are cleaner and healthier.

Halal certification is a certification process for a product or service by the provisions of Islamic Sharia. Halal certification was first carried out in the United States in the 1960s to guarantee Muslims living in non-Muslim countries to fulfil their needs according to the provisions of their religion. Halal is a mandatory requirement for every product and service consumed by Muslims and is currently considered a product quality standard. Halal quality standards are applied to providing and producing food, cosmetics, medicines, and medical products and is applied to services related to these halal products (Noordin et al. 2014).

Halal can be defined as a quality standard by Islamic Sharia law and is used in every activity carried out by Muslims (Bohari et al. 2013). Muslims choose halal products and services as a form of obedience to Islamic law. Although halal is closely related to Muslims, it does not mean that halal products only come from Muslims. Consumers of halal products from countries with Muslim minority populations have experienced a significant increase in recent years. The quality of halal products is why non-Muslims use halal products (Samori et al. 2016).

In the General Explanation of the Halal Product Guarantee Law, it is explained that the purpose is to ensure that every religious adherent worship and carry out their religious teachings, provide protection and assurance regarding the halal-ness of products consumed and used by the public by the principles of protection, justice, legal certainty, accountability and transparency, effectiveness and efficiency, and professionalism. Besides, implementing a halal product system aims to provide comfort, security, safety, and certainty of halal products' availability for the public to consume and use products and increase added value for business actors to produce and sell Halal products.

Some of the provisions in it, among others, in Article 4 regulates the obligation of halal certification, namely that products that enter, circulate, and are traded in Indonesia must be certified halal. Moreover, Article 5 mandates a new Institution to implement halal certification, namely the Halal Product Guarantee Body, which then requires a Presidential Regulation that will regulate its functions, main tasks, and organizational structure.

\section{THE IMPLEMENTING INSTITUTION HALAL PRODUCT CERTIFICATION}

The Halal Product Guarantee Law regulates each institution's authority that plays a role in the halal certification process of a product. The Halal Product Guarantee Body must cooperate with 
the Indonesian Ulema Council to carry out halal product certification and supervise Indonesia products. When viewed for law enforcement, the existence of this Halal Product Guarantee Law provides more guarantees of protection and legal certainty than before the existence of this law.

After the implementation of the Halal Product Guarantee Law, Commission VIII of the House of Representatives of the Republic of Indonesia issued a statement that they considered that the Halal Product Guarantee Body under the Ministry of Religion was still slow in carrying out its duties. It was reported that the Head of the Halal Product Guarantee Body, Sukoso, believed that the cause of the slow performance was because the Indonesian Ulema Council seemed to slow down the Halal Auditor certification process, which was a requirement for the establishment of a Halal Inspection Institution. However, this statement was refuted by evidence that the Indonesian Ulema Council had carried out certification for 142 auditors from the Halal Inspection Institution for the Indonesian Ulema Council for Food and Drug Studies (LPPOM MUI) and other candidates for the Halal Inspection Institution from several companies. Other problems also arise from business actors regarding the implementation of halal certification in Indonesia. Many business actors claim to be increasingly confused about the procedure for applying for halal certification because the community has been familiar with the Indonesian Ulema Council as the holder of the halal certification authority. Business actors have also complained about the new halal certification procedure, which is considered more complicated and confusing than the previous procedure.

In the author's opinion, in terms of its traditional strength, the Halal Product Guarantee Law is good enough to accommodate Muslim consumer rights protection. If it is further reviewed regarding the transfer of authority of the implementing Institution for halal product certification, especially to the effectiveness and easy access of business actors in applying for halal certificates, basically the process of implementing halal product certification can run optimally if there is harmonious cooperation between the institutions concerned.

The author compares the implementation of halal product certification with Sharia banking in Indonesia, which involve more than one institution, namely Bank Indonesia, which is under the Ministry of Finance, the Financial Services Authority, and the National Sharia Council of the Indonesian Ulema Council. Islamic banking in Indonesia began to be known with Bank Muamalat Indonesia (BMI) establishment in 1991. The legal basis for the operation of Islamic banking is law number 21 of 2008 on Islamic Banking. Article 1 point 7 states that what is meant by Sharia banks are banks that carry out their business based on Sharia principles. What is meant by Sharia principles by Article 1 point 12 of the Sharia Banking Act is the principle of Islamic law in banking activities based on fatwas issued by institutions that have the authority to determine fatwas in the field of Sharia.

The institution that is authorized to issue fatwas on Sharia financial institutions, including Sharia banking, is the National Sharia Council established by the Indonesian Ulema Council. At the beginning of its formation, it was motivated to realize the aspirations of Muslims regarding economic issues and to encourage the application of Islamic teachings in the economic/financial sector, which was carried out by the guidance of Islamic law, as a measure of efficiency and coordination of scholars in responding to issues related to economic problems/finance. Various problems or cases requiring a fatwa will be accommodated and discussed together to obtain a standard view in their handling by each Sharia Supervisory Board in Islamic financial institution.

Based on its establishment's background, the National Sharia Council of the Indonesian Ulema Council has the authority to issue Islamic economic fatwas, including Islamic banking. The fatwa is used as a guideline for Islamic financial institutions in carrying out their activities. Judging from the current practice of Islamic banking activities in Indonesia, the Islamic banking fatwa from the National Sharia Council of the Indonesian Ulama Council is binding on Sharia banking institutions. This means that Islamic banking institutions must follow the fatwa issued by the National Sharia Council of the Indonesian Ulema Council in carrying out their activities. Currently, nearly 100 fatwas related to Islamic financial institutions, including Islamic banking, were issued by the National Sharia Council of the Indonesian Ulema Council. So, if the Islamic banking institution does not follow or deviate from the fatwa, a warning can be given. Besides, the National Sharia Board can also propose to the Financial Services Authority to take firm action regarding 
these violations. Thus, the implementing institution for halal product certification that has been mandated in the Halal Product Guarantee Law will be useful in carrying out its duties if there is good cooperation between related institutions, such as cooperation between institutions in the field of Islamic banking was argued by the authors. The law has also emphasized each institution's primary duties and functions so that the relevant institutions need to carry out their respective roles.

\section{CONCLUSION}

The implementation of halal product certification is closely related to the protection of Muslim consumers in Indonesia. As support, an agency for implementing halal product certification was needed, which must be stated in a legal product. In 2014, the Government of Indonesia issued the Halal Product Guarantee Law and was effective in 2019. The Halal Product Guarantee Law mandates the obligation for every product circulating in Indonesia to be halal certified. Also, there is a transfer of authority to the implementing agency for halal certification, initially only carried out by the Indonesian Ulema Council, now under the Ministry of Religion's authority with an institution called the Halal Product Guarantee Agency. However, it turns out that the role of the Indonesian Ulema Council was not wholly transferred and removed. However, the Halal Product Guarantee Agency must coordinate and cooperate in carrying out halal product certification in the process. According to the author, implementing halal product certification can run if there is harmonious cooperation between the institutions concerned. An example is the institutions related to the field of Islamic banking. So, the implementing agency for halal product certification that has been mandated in the Halal Product Guarantee Law will be useful in carrying out its duties if there is good cooperation between related institutions, such as cooperation between institutions in the field of Islamic banking. This is supported by the Halal Product Guarantee Law, which regulates each implementing agency's primary duties, functions, and roles for halal product certification.

\section{REFERENCES}

Apriyantono, Anton, and Nurbowo. 2003. Panduan Belanja dan Konsumsi Halal. Jakarta: Khairul Bayaan. Asshiddiqie, Jimly. 1994. Gagasan Kedaulatan Rakyat dalam Konstitusi dan Pelaksanaannya di Indonesia. Jakarta: PT. Ichtiar Baru Van Hoeve.

Fishmen, Karen S. 1986. An Overview of Consumer Reporting Service. Maryland: National Law Publishing Corporation.

Fuady, Munir. 2000. Hukum Bisnis dalam Teori dan Praktik. Bandung: Citra Aditya Bakti.

Hartono, Sri Redjeki. 2000. Kapita Selekta Hukum Ekonomi. Bandung: Mandar Maju.

Hasan, KN. Sofyan. 2014. "Kepastian Hukum Sertifikasi dan Labelisasi Halal Produk Pangan.” Jurnal Dinamika Hukum 227-238.

Hasan, Sofyan. 2014. Sertifikasi Halal dalam Hukum Positif, Regulasi dan Implementasinya di Indonesia. Yogyakarta: Aswaja Pressindo.

Makarim, Edmon. 2003. Kompilasi Hukum Telematika. Jakarta: PT. Raja Grafindo Persada.

Mujiyono, Slamet. 2016. "Perlindungan Konsumen: Regulasi Bisnis." Jurnal Ekonomi dan Bisnis Islam.

Muslimah, Siti. 2012. "Label Halal pada Produk Pangan Kemasan dalam Perspektif Perlindungan Konsumen Muslim." Jurnal Yustisia 86-95.

Oughton, David, and John Lowry. 1997. Textbook on Consumer Law. London: Blackstore Press Ltd.

Putra, Panji Adam Agus. 2017. "Kedudukan Sertifikasi Halal dalam Sistem Hukum Nasional sebagai Upaya Perlindungan Konsumen dalam Hukum Islam.” Jurnal Ekonomi dan Keuangan Syariah 150-165.

Rasyidi, Lili. 1988. Filsafat Hukum. Bandung: Remadja Karya.

Sayekti, Nidya Waras. 2014. “Jaminan Produk Halal dalam Perspektif Kelembagaan.” Jurnal Ekonomi dan Kebijakan Publik 193-209.

Shidarta. 2004. Hukum Perlindungan Konsumen Indonesia Edisi Revisi. Jakarta: Grasindo.

Siradj, Asep Syarifuddin Hidayat dan Mustolih. 2015. "Sertifikasi Halal dan Sertifikasi Non Halal pada Produk Pangan Industri.” Jurnal Ahkam 199-210.

Syawali, Husni, and Neni Sri Imaniyati. 2000. Hukum Perlindungan Konsumen. Bandung: Mandar Maju. 